\title{
Saccharomyces telomeres assume a non-nucleosomal chromatin structure
}

\author{
Jocelyn H. Wright, ${ }^{1,2,4}$ Daniel E. Gottschling, ${ }^{1,3}$ and Virginia A. Zakian ${ }^{1,2}$ \\ ${ }^{1}$ Fred Hutchinson Cancer Research Center, Seattle, Washington 98104 USA
}

The chromatin structures of the telomeric and subtelomeric regions on chromosomal DNA molecules in Saccharomyces cerevisiae were analyzed using micrococcal nuclease and DNase $\mathbf{I}$. The subtelomeric repeats $\mathbf{X}$ and $Y^{\prime}$ were assembled in nucleosomes. However, the terminal tracts of $C_{1-3} A$ repeats were protein protected in a particle larger than a nucleosome herein called a telosome. The proximal boundary of the telosome was a DNase I hypersensitive site. This boundary between the telosome and adjacent nucleosomes was completely accessible to Escherichia coli dam methylase when this enzyme was expressed in yeast, whereas a site 250 bp internal to the telomeric repeats was relatively inaccessible. Telosomes could be cleaved from chromosome ends with nuclease and solubilized as protein-DNA complexes. Immunoprecipitation of chromosomal telosomes with antiserum to the RAP1 protein indicated that RAP1 was one component of isolated telosomes. Thus, the termini of chromosomal DNA molecules in yeast are assembled in a non-nucleosomal structure encompassing the entire terminal $\mathrm{C}_{1-3} \mathrm{~A}$ tract. This structure is separated from adjacent nucleosomes by a region of DNA that is highly accessible to enzymes.

[Key Words: Telomere; chromatin; RAP1; DNase I; MNase; dam methylase]

Received November 11, 1991; revised version accepted December 23, 1991.

Telomeres are specialized structures that stabilize the ends of linear eukaryotic chromosomes. In most organisms, the ends of chromosomes are comprised of a variable number of simple, satellite-like repeats. In the majority of telomeric repeats, the strand running $5^{\prime} \rightarrow 3^{\prime}$ toward the terminus of the chromosome has clusters of three or more G residues (for review, see Zakian 1989). Chromosomes in Saccharomyces cerevisiae end with $\sim 350$ bp of the heterogenous sequence, $5^{\prime}-\mathrm{C}_{2-3} \mathrm{~A}(\mathrm{CA})_{1-6^{\prime}}$ 3', abbreviated $\mathrm{C}_{1-3} \mathrm{~A}$ (Shampay et al. 1984; Wang and Zakian 1990).

Most organisms also possess telomere-associated middle repetitive elements located internal to the satellitelike terminal repeats. In yeast, there are two such elements called $Y^{\prime}$ and $X$ (Chan and Tye 1983). $Y^{\prime}$, a highly conserved repeat that is found in long $(6.7 \mathrm{~kb})$ and short $(5.2 \mathrm{~kb})$ versions, is present in $0-4$ copies at individual telomeres (Chan and Tye 1983; Zakian and Blanton 1988; Louis and Haber 1990). The X element, which varies in length from 0.3 to $3.7 \mathrm{~kb}$ (Chan and Tye 1983), is not well defined. Some telomeres bear $X$, but not $Y^{\prime}$ (e.g., see Button and Astell 1986). When $X$ and $Y^{\prime}$ are present

\footnotetext{
${ }^{2}$ Department of Pathology, University of Washington, Seattle, Washington 98195 USA.

${ }^{3}$ Department of Molecular Genetics and Cell Biology, University of Chicago, Chicago Illinois 60637 USA.

${ }^{4}$ Corresponding author.
}

at the same telomere, $\mathrm{X}$ is centromere proximal to $\mathrm{Y}^{\prime}$. $\mathrm{X}$ and $\mathrm{Y}^{\prime}$ elements, as well as tamdemly repeated $Y s$, are often separated by shorter tracts of $\mathrm{C}_{1-3} \mathrm{~A}$ DNA (Walmsley et al. 1984; Louis and Haber 1990).

Telomeres are thought to be essential to protect the ends of chromosomes from degradation and end-to-end fusions. Telomeres are also necessary to prevent the gradual loss of DNA that would result from replication of a linear DNA molecule by conventional DNA polymerases. On the basis of the observation that telomeres associate both with one another and with the nuclear envelope, telomeres are postulated to have a role in the positioning of chromosomes within the nucleus (for review, see Zakian 1989).

Presumably, the cell distinguishes a telomere from a broken chromosome end, at least in part, by the presence of telomere-specific DNA-binding proteins. Telomerebinding proteins could identify the telomere to the replication machinery, regulate telomere accessibility to nucleases and transcription factors, and mediate telomere associations both with other telomeres and with the nuclear envelope. Evidence for specific telomeric protein-DNA complexes has been found in other systems. The ends of all of the gene-size, subchromosomal DNA molecules in the macronucleus of the ciliate $\mathrm{Ox}$ ytricha were found to be assembled in non-nucleosomal, protein-DNA complexes (Gottschling and Cech 1984; Price and Cech 1987). The chromatin structures of the 
terminal regions of extrachromosomal ribosomal DNA (rDNA) molecules from Tetrahymena (Chiou and Blackburn 1981; Budarf and Blackburn 1986) and slime molds (Edwards and Firtel 1984; Lucchini et al. 1987) have been analyzed; on the basis of nuclease protection patterns and salt solubility, these telomeric repeats were also found to be assembled in non-nucleosomal chromatin structures.

Specific terminus-binding proteins that copurify with chromosome ends have been isolated from the ciliates Oxytricha (Gottschling and Zakian 1986) and Euplotes (Price 1990). These proteins bind tenaciously, yet noncovalently, to the native DNA ends, remaining bound even in $2 \mathrm{M}$ salt (Gottschling and Zakian 1986; Price and Cech 1989). Their presence on DNA termini account for only the distal portion of the non-nucleosomal terminal structure defined by chromatin mapping studies, suggesting the presence of additional proteins in the terminal complex (Price and Cech 1987).

Proteins that bind specifically to yeast telomeric repeats in vitro have been identified in S. cerevisiae (Berman et al. 1986; Buchman et al. 1988; Liu and Tye 1991). $R A P 1$, the gene encoding one of the yeast proteins, has been cloned and shown to be essential for growth (Shore and Nasmyth 1987). The fact that cells overexpressing (Conrad et al. 1990) and underexpressing (Conrad et al. 1990; Lustig et al. 1990) RAP1 have an altered telomere structure indicates that RAP1 interacts with telomeric sequences in vivo. This interpretation is supported by the demonstration that some RAPl protein copurifies with the termini of linear plasmids (Conrad et al. 1990). Two other proteins, TGF- $\beta$ and TGF- $\alpha$, have been identified and shown to bind specifically to $C_{1 \cdot 3} A$ and to the junction of $\mathrm{X}$ and $\mathrm{C}_{1-3} \mathrm{~A}$ sequences, respectively (Liu and Tye 1991). None of the identified yeast proteins requires an authentic end for binding.

As part of our goal to identify structural proteins that bind to yeast telomeres in vivo, we have determined the chromatin structure of telomeric and subtelomeric regions on chromosomal DNA molecules. This report demonstrates that the ends of authentic yeast chromosomes, like the termini of subchromosomal DNA molecules in ciliates and slime molds, are organized in a non-nucleosomal chromatin structure. This structure may be a general feature of all eukaryotic telomeres containing satellite-like repeats. Telosomes can be cleaved from chromosome ends and solubilized in protein-bound form and shown to have properties that distinguish them from nucleosomes. In contrast, the subtelomeric $X$ and $\mathrm{Y}^{\prime}$ repeats are packaged in nucleosomes.

\section{Results}

$X$ and $Y^{\prime}$ elements, but not $C_{1-3} A$ repeats, are assembled in nucleosomes

Micrococcal nuclease ( $\mathrm{MNase}$ ) is a relatively non-sequence-specific endonuclease that is diagnostic for nucleosomes in that it cleaves preferentially in the linker region between nucleosomal core particles (for review, see van Holde 1988). Compared with other organisms, the internucleosomal linker length in $S$. cerevisiae is short, giving an MNase repeat length of $\sim 160 \mathrm{bp}$ (Thomas and Furber 1976; Lohr and Ide 1979).

MNase was used to examine the protection pattern of telomeric sequences (Fig. 1). Yeast nuclei were isolated from spheroplasts and subjected to MNase digestion. DNA was purified from digested nuclei at different time points and analyzed by Southern blotting. To control for any sequence preference of MNase, a similar time course was performed on naked DNA. The blots of digested chromatin and DNA were hybridized to a $\mathrm{C}_{1-3} \mathrm{~A}$ probe and to probes from conserved regions of the $\mathrm{X}$ and $\mathrm{Y}^{\prime}$ elements.

When the MNase chromatin digestions were hybridized with the $\mathrm{X}$ or $\mathrm{Y}^{\prime}$ probes, ladders of partial digestion products characteristic of nucleosomes were detected (Fig. 1). These protection patterns were indistinguishable from profiles obtained by ethidium bromide staining of the gel prior to blotting or by probing with structural genes such as LEU2 or TRP1 (data not shown). Thus, the $\mathrm{X}$ and $\mathrm{Y}^{\prime}$ sequences, like the bulk of the genome, are assembled in nucleosomes. A different protection pattern was seen when the same blot was probed with the $\mathrm{C}_{1-3} \mathrm{~A}$ probe (Fig. 1). Instead of nucleosomal-size particles, $\mathrm{C}_{1.3}$ A DNA was protected in DNA fragments of a larger and more heterogeneous size than a nucleosome. These data suggest that nucleosomes do not continue out to the very ends of chromosomes in yeast.

Telomeres possess a DNase I hypersensitive site near the $C_{1 \cdot 3} A$-unique DNA junction

At low concentration, DNase I can be used to identify sequences free of nucleosomes or bound by other nonnucleosomal proteins (for review, see Gross and Garrard 1988). These regions appear as chromatin-specific, DNase I hypersensitive sites. A digestion series on nuclei and naked DNA was performed with DNase I and probed with telomeric sequences (Fig. 2). In DNase I-digested chromatin, the $\mathrm{C}_{1-3} \mathrm{~A}$ probe hybridized to a heterogeneous smear, corresponding to a population of small DNA fragments averaging $400 \mathrm{bp}$ in size. This smear appeared at very early time points in the digestion when the majority of the DNA was still virtually undigested (Fig. 2). The fact that the smear persisted for a number of time points without diminishing in size suggested that these DNA sequences were protected in a protein-dependent structure. The early appearance of these small terminal DNA fragments indicated that the proximal boundary of this structure was a hypersensitive site for DNase I. Comparison of the chromatin and naked DNA digestion patterns revealed that the hypersensitive site was chromatin specific (Fig. 2). When the DNase I-digested chromatin was reprobed with $\mathrm{Y}^{\prime}$ (Fig. 2), $X$, or single-copy DNA sequences (data not shown), the digestion pattern was similar to that seen for bulk DNA as deduced from the ethidium bromide staining pattern and was thus representative of nucleosomal DNA. Additional hypersensitive sites giving bands at 

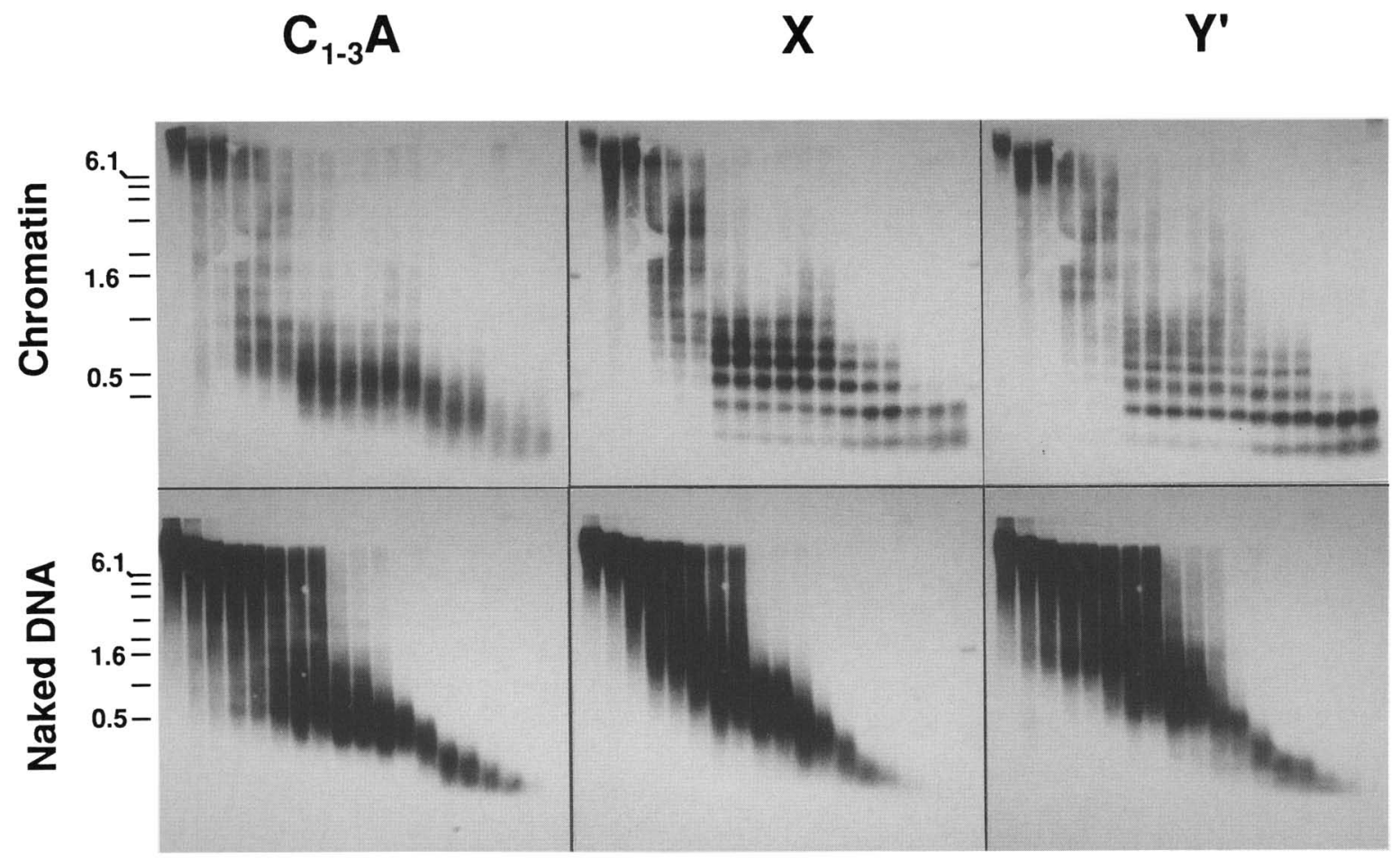

Figure 1. MNase digestion time courses of nuclei and naked DNA. (Top panels) Sequential probings with $\mathrm{C}_{1-3} \mathrm{~A}, \mathrm{X}$, and $\mathrm{Y}^{\prime}$ of a blot of a $1 \%$ agarose gel of an MNase digestion time course of nuclei. DNA was purified from the digested nuclei throughout the time course and loaded in successive lanes on the gel. From left to right, the time points in seconds were $0,15,30,45,60,75,90,105,120$, $150,180,210,240,270,300,600,900$, and 1200 . (Bottom panels) Sequential probings with $C_{1-3} A, X$, and $Y^{\prime}$ of a blot of a $1 \%$ agarose gel of an MNase digestion time course on purified genomic DNA. The time points in seconds from left to right were 0 , 15, 30, 45, 60, $75,90,105,120,180,240,300,600,1200,1200(2 \times$ MNase concentration), $1200(4 \times), 1200(8 \times)$, and $1200(10 \times)$. The positions of fragments from the BRL $1-\mathrm{kb}$ ladder are indicated at left.

$\sim 6.5 \mathrm{~kb}$ and $\sim 3.5 \mathrm{~kb}\left(\mathrm{C}_{1-3} \mathrm{~A}\right)$ or $\sim 3.2 \mathrm{~kb}\left(\mathrm{Y}^{\prime}\right)$ were apparent in both the $\mathrm{C}_{1-3} \mathrm{~A}$ and $\mathrm{Y}^{\prime}$ hybridizations to the DNase I chromatin time course (Fig. 2). Bands at 3.2 or $3.5 \mathrm{~kb}$ (or both) were also seen with the $\mathrm{X}$ and LEU2 probes (data not shown). In contrast, the $\sim 6.5-\mathrm{kb}$ band was observed only with the $\mathrm{C}_{1-3} \mathrm{~A}$ and $\mathrm{Y}^{\prime}$ probes.

\section{$C_{1-3} A$}

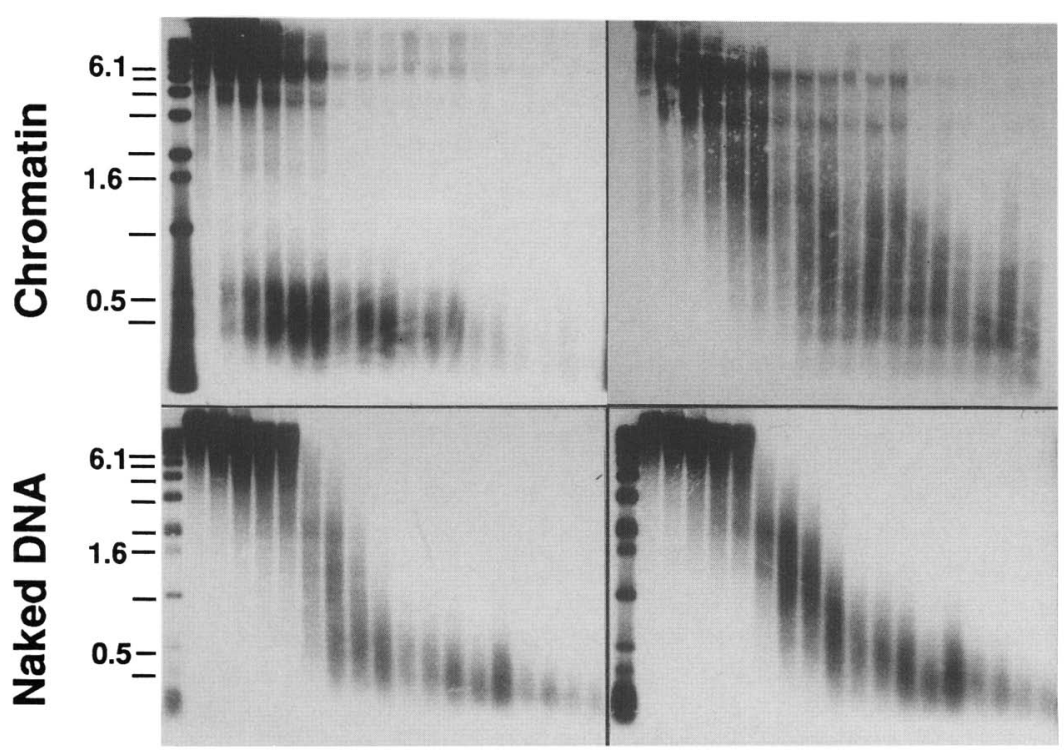

Figure 2. DNase I digestion time courses of nuclei and naked DNA. (Top panels) Sequential probings with $\mathrm{C}_{1-3} \mathrm{~A}$ and $\mathrm{Y}^{\prime}$ of a blot of a $1 \%$ agarose gel of a DNase I digestion time course on nuclei. DNA was purified from nuclei throughout the time course and loaded in successive lanes on the gel. From left to right, the time points in seconds were $0,15,30,60,90,120,150$, $180,210,240,270,300,330,360,390,420,450$, and 480 . (Bottom panels) Sequential probings with $\mathrm{C}_{1-3} \mathrm{~A}$ and $\mathrm{Y}^{\prime}$ of a blot of a $1 \%$ agarose gel of a DNase I digestion time course on purified genomic DNA. The time points in seconds from left to right were $0,15,30,45,60,90,120,150$, $180,210,240,270,300,330,360,390,420$, and 480. The positions of fragments from the BRL $1-\mathrm{kb}$ ladder are indicated at left. 
Figure 3. Schematic representation of modifications made to chromosome VII-L. The $3^{\prime}$ end of the $A D H 4$ gene was used to target the $U R A 3$ gene and a short tract of $\mathrm{C}_{1-3} \mathrm{~A}$ sequence to chromosome VII-L. Integration of this DNA at $A D H 4$ deleted the most distal $\sim 20 \mathrm{~kb}$ of chromosome VII-L. The $\mathrm{C}_{1-3} \mathrm{~A}$ sequence on the transforming fragment was elongated in vivo to full length. This figure is not drawn to scale. Positions of probes used in Fig. 4 are indicated.

Examination of the naked DNA time courses revealed that $\mathrm{C}_{1-3} \mathrm{~A}$ DNA was digested with both nucleases at a rate similar to other sequences. This result indicated that the $C_{1-3} A$ DNA itself was neither hypo- nor hypersensitive to these two nucleases (Figs. 1 and 2).

\section{Nuclease mapping of a single, modified yeast telomere defined the size of the telosome}

In the yeast strain used here, $\sim 20 \%$ of the $C_{1-3} \mathrm{~A}$ hybridization was to interstitial, rather than terminal, $\mathrm{C}_{1-3} \mathrm{~A}$ tracts. Therefore, the precise protection pattern of terminal $C_{1-3} A$ tracts could not be deduced using $C_{1-3} A$ as a probe. To map the chromatin structure of telomeric $C_{1}$. 3A DNA in more detail, the telomere region of chromosome VII-L was modified (Fig. 3). Homology to the ADH4 gene on chromosome VII (Walton et al. 1986) was used to create a uniquely marked telomere. The $\sim 20 \mathrm{~kb}$ distal to $A D H 4$ was deleted and replaced with the URA3 gene and a short tract of $\mathrm{C}_{1-3} \mathrm{~A}$ that is elongated in vivo to form a full-length telomere (Gottschling et al. 1990). This modified chromosome VII has a mitotic stability indistinguishable from that of the unmodified parent chromosome (L.L. Sandell and V.A. Zakian, unpubl.), demonstrating that the modified telomere performs the normal mitotic functions carried out by authentic yeast telom- eres with high fidelity. Because the telomere modification was made in a strain in which $U R A 3$ was deleted from its normal location on chromosome $V$, the DNA immediately adjacent to the terminal $\mathrm{C}_{1-3} \mathrm{~A}$ tract on chromosome VII-L was unique-sequence DNA.

Isolated nuclei from a strain carrying the modified VII-L chromosome were treated for varying times with MNase (Fig. 4). The locations of the nuclease cut sites were mapped by indirect end labeling (Nedospasov and Georgiev 1980; Wu 1980). Aliquots of DNA purified from different MNase time points were digested with PstI and hybridized to the 100-bp PstI-RsaI fragment of URA3 (Fig. 4C, panels 2 and 3). The top band in the gels represents the full-length terminal PstI fragment. Bands below this full-length fragment are MNase partial digestion products from the PstI site toward the terminus. The mapped positions of these partial digestion products are presented schematically in Figure 4B. No partial digestion products were detected where cleavage had occurred within the $\mathrm{C}_{1-3} \mathrm{~A}$ repeats. Therefore, either the telomeric repeats were protected but separated from adjacent nucleosomes by a strong site for MNase or the $\mathrm{C}_{1-3} \mathrm{~A}$ repeats were quickly degraded.

To distinguish between these possibilities, the complementary experiment was done. In this case, the telomere was used in place of a restriction site and the

Figure 4. Nuclease mapping of the modified chromosome VII-L telomere. $(A)$ The deduced chromatin structure of the terminal 1.2 $\mathrm{kb}$ of chromosome VII- $\mathrm{L}$ is shown with nucleosomes represented as spheres and the telosome as an ellipse. (B) A diagram of the mapped region of chromosome VII-L is drawn to scale. The locations of the probes are shown as solid and hatched boxes. Symbols marking the location of nuclease cut sites are ( $\nabla)$ MNase chromatin cut site, (vertical lines) MNase naked DNA cut sites, and (O) DNase I chromatin cut sites. DNase I naked DNA cut sites are not shown schematically (see $D$, panel 3). The numbered lines below the map show the location of partial digestion products observed with MNase digestion of chromatin. The thickness of the lines corresponds to the relative abundance of each partial digestion product: the thick lines were detected as major bands and the thin lines as minor bands. The location of $P s t \mathrm{I}(\mathrm{P})$ and $B a m H I(B)$ sites are indicated. $(C)$ Blots of the MNase and DNase I digestions in nuclei from which locations of the partial digestion products mapped in $B$ were deduced. The numbers $1-8$ indicate the partial digestion products that correspond to numbered lines in $B$. The probe used to hybridize to each blot is indicated above each panel. (Panel 1) MNase-digested nuclei probed with the distal probe. The time points in seconds from left to right were $0,15,30,45,60,75,90,105,120$. (Panels 2 and 3) MNase digested nuclei probed with the URA3 probe; two different gels which were run to differing extents are shown. In panel 2 , partial digestion products 6 and 7 were run off the gel. Time points in panel 2 are identical to those in panel 1. In panel 3 , the time points in seconds from left to right are 0,60,180,300, and 600. (Panel 4) DNase I-digested nuclei probed with the URA3 probe. Time points in seconds from left to right are 120,180, and 300. The DNA samples on all blots probed with URA3 were digested with PstI prior to running the gel. $(D)$ Blots of purified DNA samples digested with MNase and DNase I are shown. Hybridization probes are indicated above each panel; the nuclease used is indicated below the panels. The time points in seconds from left to right are 90 , 105, $120,180,240$, and 300 (panel 1); 60, 120, 180, and 300 (panel 2); 120, 150, 180, and 210 (panel 3). 
A

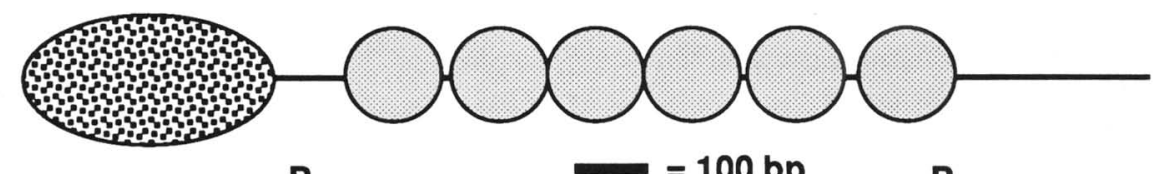

B
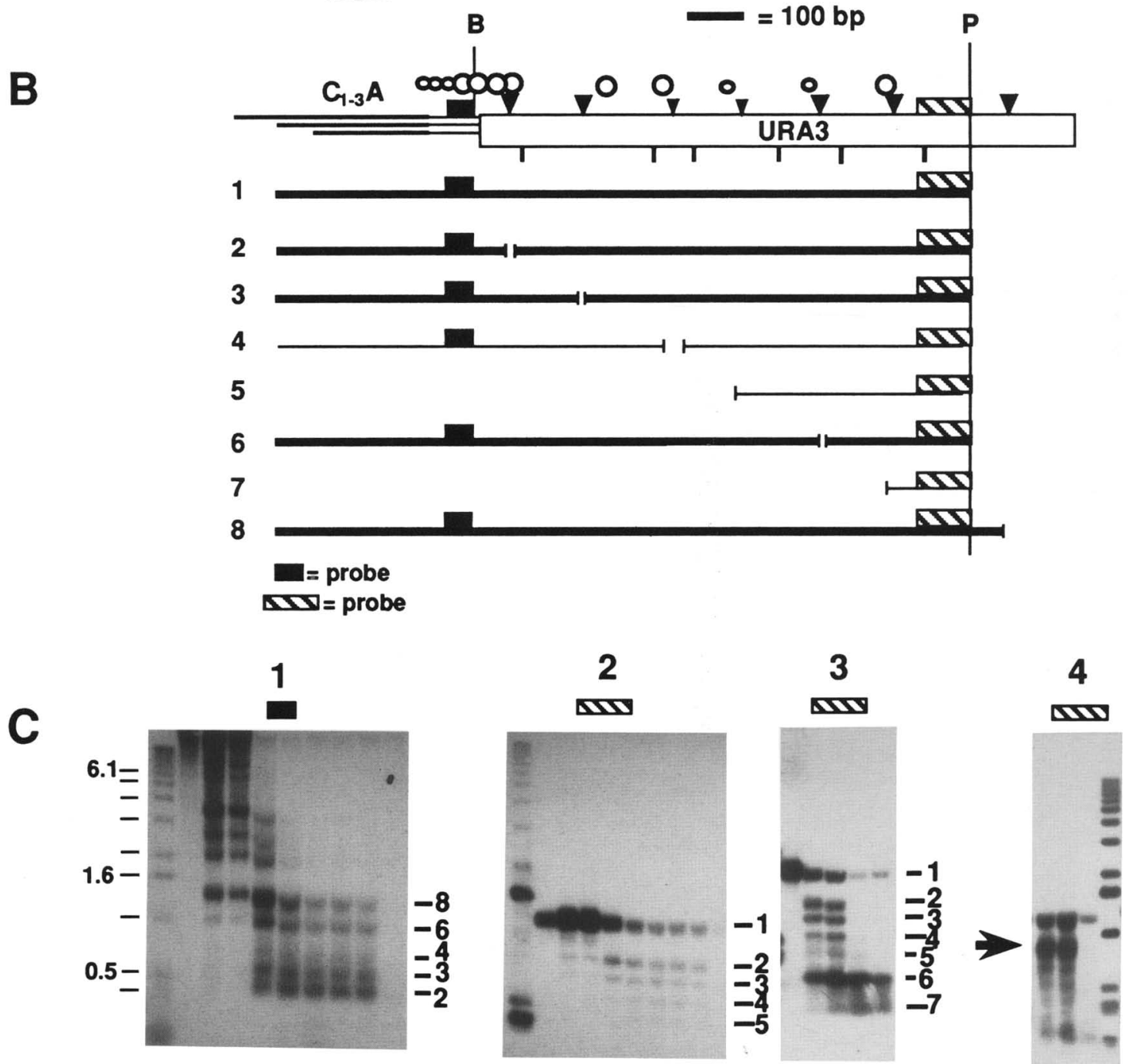

MNase

DNase I

D

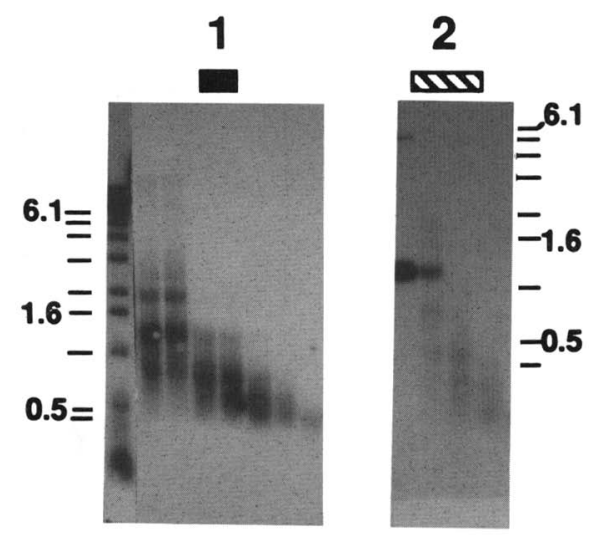

MNase

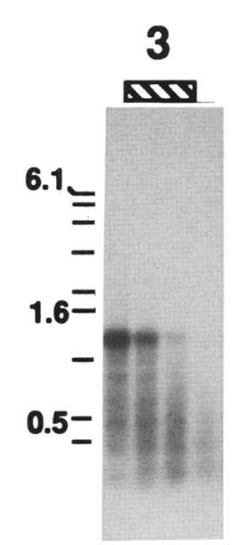

\section{DNase I}

Figure 4. (See facing page for legend.) 
unique sequence directly adjacent to the $\mathrm{C}_{1-3} \mathrm{~A}$ repeats was used to probe for the terminal partial digestion products (Fig. 4C, panel 1). When the terminal partial digestion products were positioned on the map based on the assumption that the $\mathrm{C}_{1-3} \mathrm{~A}$ tract remained intact, they gave the mirror image of those products seen with the more internal URA3 probe (Fig. 4B). The mapped positions shown in Figure 4B were the only interpretation that agreed with the data obtained with the URA3 probe in terms of the relative size and abundance of each pair of digestion products arising from the same cleavage event. Thus, by probing directly for the terminal partial digestion products, it was possible to demonstrate that the terminal $\mathrm{C}_{1-3} \mathrm{~A}$ tract persisted during the digestion time course. The naked DNA digestions probed with the distal probe (Fig. 4D, panel 1 ) showed a smear in the region of the gel where distinct partial digestion products were seen with this DNA in chromatin. This result indicated that the protection of distinct terminal partial digestion products was protein dependent.

The chromatin structure deduced from these data is presented in Figure 4A. Highly phased nucleosomes were detected across the $U R A 3$ gene. A structure two and onehalf times the size of a nucleosome encompassed the most distal $420 \pm 75 \mathrm{bp}$, including the entire tract of $\mathrm{C}_{1.3} \mathrm{~A}$ DNA and $\sim 130 \mathrm{bp}$ of adjacent unique DNA. This non-nucleosomal structure is defined here as a telosome.

A similar analysis of the chromosome VII-L modified telomere was done with DNase I (Fig. 4C, panel 4). When the DNase I partial digestion products were examined with the $U R A 3$ probe, the observed cut sites were similar to those mapped with MNase, except the most distal site for DNase I was $\sim 100 \mathrm{bp}$ wide and stronger than the corresponding MNase-cut site (Fig. 4B, open circles above the map). Experiments using the unique DNA next to the $\mathrm{C}_{1-3} \mathrm{~A}$ repeats to probe DNase I digestions were not informative because this probe fell within the 100-bp-wide DNase I hypersensitive site /data not shown). The results with DNase I redefined the size of the telosome on chromosome VII-L to $320 \pm 75$ bp. Presumably, the larger size deduced for the telosome from the analysis of MNase-digested DNA was the result of the sequence preference of MNase within the DNase I hypersensitive region on this modified telomere.

Nucleosomes across the URA3 gene at chromosome VII-L were highly phased with respect to underlying sequence. However, the positions of nucleosomes on the telomeric URA3 gene were identical to the positions of the nucleosomes when URA3 was at its normal location on chromosome $\mathrm{V}$ (data not shown) or when URA3 was present on a circular plasmid (Thoma 1986). Thus, the positioning of nucleosomes on URA3 appeared to be unaffected by proximity to the telomere as seen with these nucleases. Cells used for chromatin mapping were grown under conditions that repress expression of telomere-adjacent genes (Gottschling et al. 1990). The fact that the placement of nucleosomes on the URA3 gene was the same when URA3 transcription was repressed by proximity to the telomere (Fig. 4A) as it is when the gene is transcribed (Thoma 1986) suggests that changes in nu- cleosome positioning are not responsible for telomeric position effect repression.

Chromatin structure of a natural, non- $Y^{\prime}$ telomere revealed that proximity to a telomere has little effect on adjacent chromatin structure

The chromatin structure of a single unmodified telomere was also determined. Although the telomeric regions of most yeast chromosomes contain many kilobases of repetitive DNA, on chromosome I, the $3^{\prime}$ end of the PHO11 gene is only $\sim 3.6 \mathrm{~kb}$ from the right end of the chromosome (Venter and Horz 1989). PHO12, an acid phosphatase gene virtually identical to PHO11, is located subtelomerically, $\sim 8.5 \mathrm{bp}$ from one end of chromosome VIII (Steensma et al. 1989; Venter and Horz 1989). These $P H O$ genes are part of a large duplication in which the $\sim 20 \mathrm{~kb}$ of sequence centromere proximal to PHO11 on chromosome I is also present on chromosome VIII (Steensma et al. 1989). The restriction maps of DNA distal to the PHO genes on chromosome I and chromosome VIII were similar, indicating that the duplicated region extended to within $\sim 500$ bp of the terminus of chromosome I-R (data not shown). This duplicated region does not contain $\mathrm{Y}^{\prime}$ but does contain $\mathrm{X}$ DNA (see Materials and methods).

Cloned fragments containing the PHO11 gene were used to construct two isogenic strains in which a $5-\mathrm{kb}$ region containing either PHO11 or PHO12 was deleted. In both strains, mapping was carried out with a probe from within the deleted region, such that each strain contained a single copy of the probe, located either $1.6 \mathrm{~kb}$ from the right end of chromosome I (PHO11) or $6.5 \mathrm{~kb}$ from one end of chromosome VIII (PHO12). MNase and DNase I were used to determine the structure of regions distal to PHO11 and PHO12 in chromatin and in naked DNA (Fig. 5). Chromatin mapping was carried out on cells grown in rich medium, conditions known to repress transcription of these PHO genes (Bostian et al. 1983). Because of the profound sequence specificity of MNase in these regions (Fig. 5A), it was not possible to assess whether the telomere adjacent DNA was in nucleosomes. However, with both nucleases the chromatin structure of these two regions was very similar, except that with DNase I, the hypersensitive site that defined the boundary of the telosome on chromosome I-R was a weaker site on chromosome VIII (Fig. 5B). Although the chromatin cleavage patterns for the two sequences were very similar, they were off set from each other by $\sim 30 \mathrm{bp}$ (Fig. 5A). Because this $\sim 30$ bp difference was also observed on naked DNA controls and with several restriction enzymes (Fig. 5B and data not shown), it is most easily explained by the presence of a 30-bp segment on chromosome VIII that is missing on chromosome I. Thus, proximity to the telomere created a DNase I hypersensitive site near the junction between the $\mathrm{C}_{1-3} \mathrm{~A}$ repeats and unique-sequence DNA but had no other major effects on the chromatin structure of the adjacent sequences that were revealed by these nucleases (Fig. $5 B)$. 
A

\section{nuclease D D H H M M chromosome 181881}

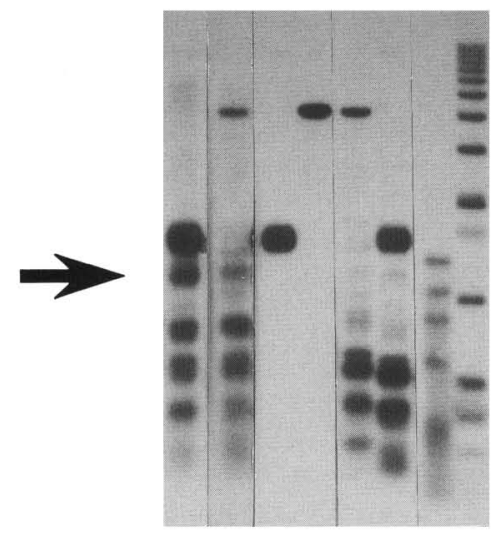

Chromatin

\section{DDHHM M \\ 188118}

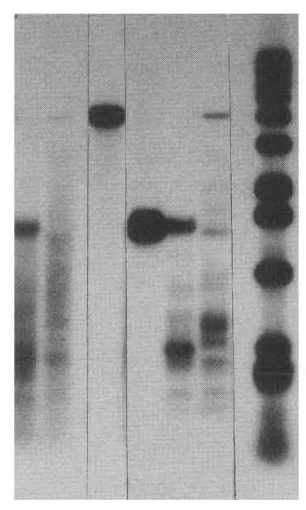

Naked DNA

B

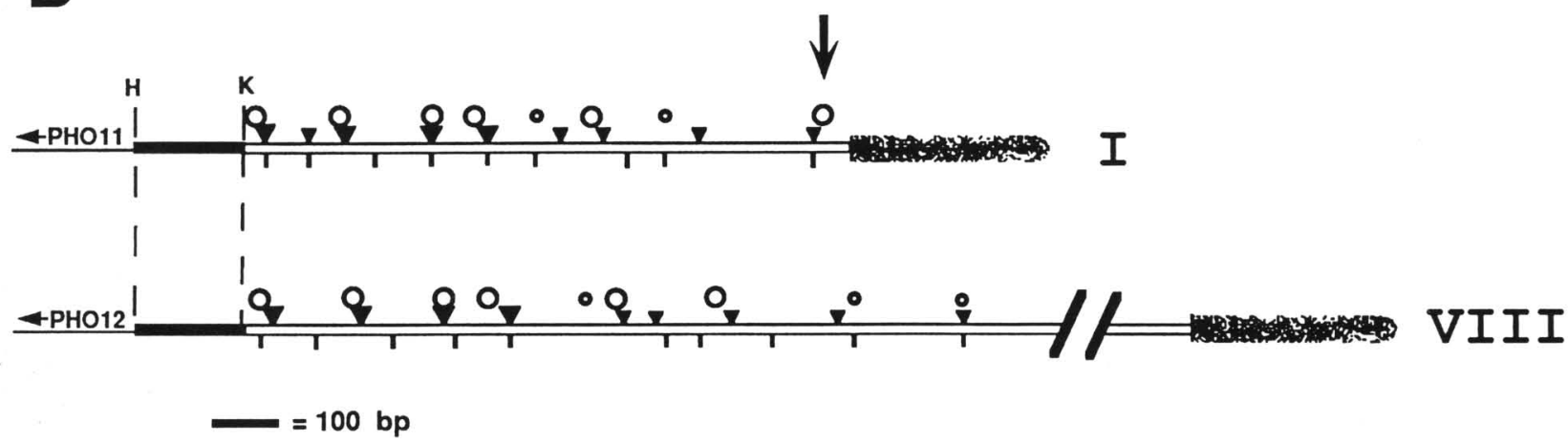

Figure 5. Nuclease mapping of a sequence located both at the chromosome $\mathrm{I}-\mathrm{R}$ telomere and subtelomerically on chromosome VIII. (A) (left) DNA digested with MNase (M) or DNase I (D) in nuclei, as well as HindIII-digested naked DNA (H). Nuclei were prepared from the yeast strain YS11 $\Delta$ UL $\Delta$ to determine the structure on chromosome VIII (lanes 8) and from strain YS12 2 UL $\Delta$ to determine the structure on chromosome I-R (lanes 1). The time points in seconds were D-8, 300; D-1, 300; M-8, 120; and M-1, 180. (Right) The naked DNA controls for these experiments. Time points in seconds were D-1, 60; D-8, 90; M-1, 120; and M-8, 120. All samples were digested with HindIII prior to loading the gels. Marker lanes are ${ }_{\phi} \mathrm{X}$ HaeIII and BRL 1-kb ladder (left), and BRL l-kb ladder (right). In both panels, all lanes were from the same gel but were rearranged for easier comparison. $(B)$ Schematic drawings of the regions mapped on chromosome I-R (top) and chromosome VIII (bottom) are presented. Cleavage sites are ( $\mathbf{\nabla})$ MNase chromatin cut sites, $(O)$ DNase I chromatin cleavage sites, and (vertical lines) MNase naked DNA cut sites. A larger triangle or circle represents a stronger cut site. The location of the DNA used as a hybridization probe in $A$ is shown as a solid rectangle. The speckled region represents the terminal tract of $\mathrm{C}_{1-3}$ A DNA. HindIII $(\mathrm{H})$ and $K p n I(\mathrm{~K})$ sites are indicated. This map is drawn to scale. The arrows in $A$ and $B$ denote the location of the telomere specific DNase I hypersensitive site.

The boundary between the telosome and adjacent nucleosomes is accessible to Escherichia coli dam methylase in vivo

Constitutive expression of the Escherichia coli dam DNA methylase gene in $S$. cerevisiae results in the in vivo modification of GATC sequences along the yeast genome. Other than minor effects on mitotic recombination rates, yeast cells expressing the methylase grow normally (Hoekstra and Malone 1985). The extent of adenine methylation that occurs in vivo can be mea- sured by comparing the relative cleavage of isolated genomic DNA with restriction enzymes that cleave at the sequence modified by the dam methylase: Cleavage at GATC by Sau3A is insensitive to methylation, whereas cleavage at GATC by DpnI occurs only if the site is methylated on both strands. The persistence of large (>10 kb) DNA fragments in DpnI digestions of genomic DNA from cells expressing the dam methylase suggests that some regions of the yeast genome are inaccessible to the methylase activity (Hoekstra and Malone 1985). 
The accessibility of two GATC sites near the telomere of chromosome VII-L was determined in yeast cells expressing the dam methylase gene. This experiment was carried out in a strain bearing a modification of chromosome VII-L very similar to that depicted in Figure 3 in which the URA3 gene is adjacent to the telomere (Gottschling et al. 1990). In this strain there are two GATC sites, 200 bp apart, near the chromosome VII-L telomere: Site 1 is $50 \mathrm{bp}$ and site 2 is $250 \mathrm{bp}$ internal to the start of the terminal $\mathrm{C}_{1-3} \mathrm{~A}$ tract (Fig. 6A). These experiments were performed on cells growing in rich medium, in which case transcription of $U R A 3$ is repressed by its proximity to the telomere (Gottschling et al. 1990).

The GATC site closest to the $\mathrm{C}_{1-3} \mathrm{~A}$ tract (site 1) was cleaved by DpnI in $\sim 100 \%$ of the DNA molecules isolated from cells expressing the dam methylase. Thus, site 1 was methylated at virtually all chromosome VII-L telomeres in vivo. In contrast, site 2 was cleaved by $D p n I$ in only $\sim 30 \%$ of the DNA molecules, whereas this same site was cleaved by Sau3A in all molecules (Fig. 6B). Thus, site 2, located within the URA3 gene, was methylated in $30 \%$ of the chromosome VII-L telomeres. When the URA3 gene was at its normal locus on chromosome $\mathrm{V}$ (Fig. 6), or when URA3 was located near the chromosome VII-L telomere in mutant strains that relieve transcriptional repression of telomeric genes (Aparicio et al. 1991), the GATC sequence within URA3 (site 2) was $100 \%$ methylated (Gottschling 1992). In contrast, the GATC sequence at site 1 located within the DNase I hypersensitive region that links the telosome to adjacent nucleosomal chromatin was completely accessible to the methylase in vivo under all conditions and in all strains tested (Fig. 6 and data not shown). These data showed that the DNA at the proximal boundary of the telosome is highly accessible to enzymes not only in isolated nuclei but also in vivo.

\section{Solubilized telosomes retain bound protein}

To investigate the nature of the protein-DNA interactions at telomeres, methods were developed for solubilizing telosomes. Telosomes were released from chromosomes by digestion with MNase or DNase I, or from the modified version of chromosome VII-L by digestion with a restriction enzyme with a recognition site in the nuclease-accessible region. Nuclei were then disrupted, and insoluble material was removed by centrifugation to yield a chromatin supernatant. The chromatin supernatant contained $\sim 80 \%$ of the DNA that hybridized to $C_{1}$. 3A. The fraction of nucleosomal DNA in the chromatin supernatant ranged from $10 \%$ to $80 \%$, depending on which nuclease was used, and was inversely proportional to the size of the digestion products.

Chromatin supernatants prepared from MNase-digested nuclei were analyzed by agarose gel electrophoresis and Southern blotting, with and without prior digestion by proteinase $\mathrm{K}$ (Fig. 7A). Probing of these blots with $\mathrm{C}_{1-3} \mathrm{~A}$ revealed that the heterogeneously sized telomeric fragments were shifted quantitatively in mobility in a protein-dependent manner. This result demonstrated that the solubilized telosomes were protein bound. In different experiments, the telosome migrated to the approximate position of either the 1.6- or the 1.0-kb DNA molecular weight markers.

Proteins in yeast extracts can bind to exogenously added telomeric DNA in vitro to yield a specific gel shift (Berman et al. 1986). Competition experiments were carried out to determine whether the proteins responsible

Figure 6. In vivo methylation of the region near the telomere of the modified chromosome VII-L. $(A)$ The diagram represents the structure near the telomere of chromosome VII-L after modification by insertion of the URA3 gene (see Fig. 3). The thick shaded region represents the terminal $\mathrm{C}_{1-3} \mathrm{~A}$ tract, the solid rectangle indicates the sequence used for hybridization in $B$, the open rectangle represents the $U R A 3$ gene, and 1 and 2 mark the locations of GATC sites. Site 1 is also a BamHI site. The lower portion of the diagram depicts the expected fragments, A through $\mathrm{E}$, detected by the hybridization probe if DpnI cleavage does or does not occur at sites 1 or 2. $B$ DNA was isolated from a strain in which the E. coli dam methylase gene is expressed in vivo and which contains a mutation in the URA3 gene (strain
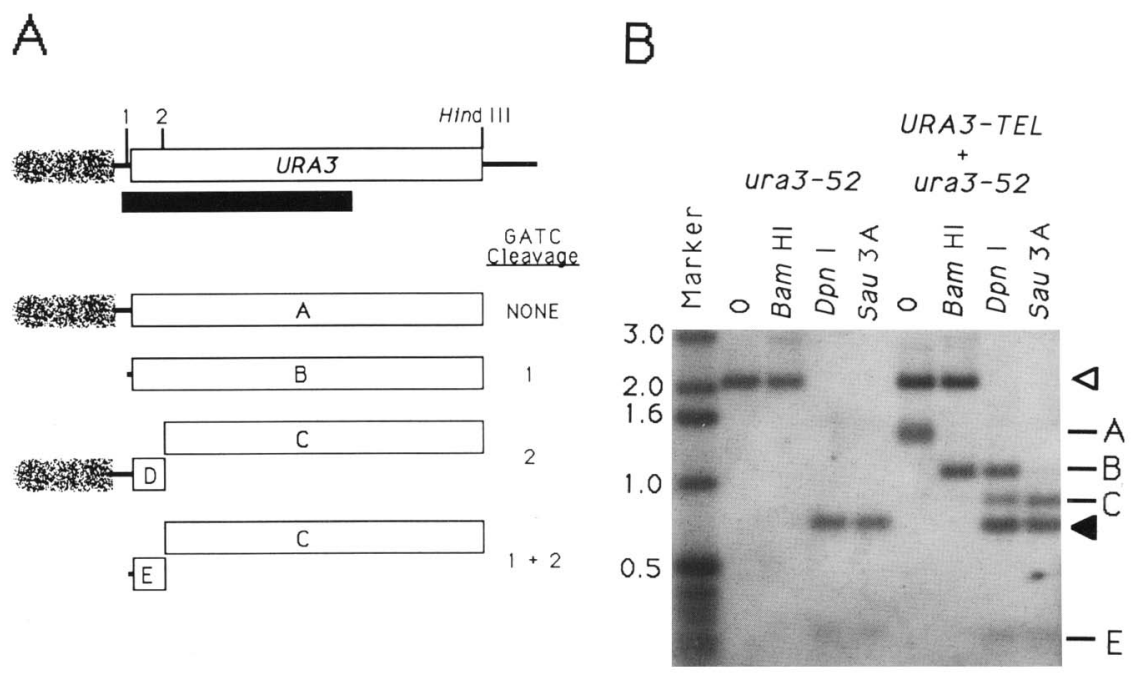

UCC1023, marked ura3-52) or from the same strain after modification of chromosome VII-L (strain UCC1021, marked URA3TEL + ura3-52). DNA was digested with HindIII alone (marked 0) or with HindIII plus either BamHI, DpnI, or Sau3A and run on an agarose gel. The DNA was hybridized to the probe shown in $A$. The open arrowhead indicates the HindIII band from the ura3-52 locus; the closed arrowhead indicates the band from the same locus after digestion with Sau3A. Fragments A-E are derived from the telomere region of chromosome VII-L as shown schematically in $A$. The marker lane is the $1-\mathrm{kb}$ BRL ladder. 


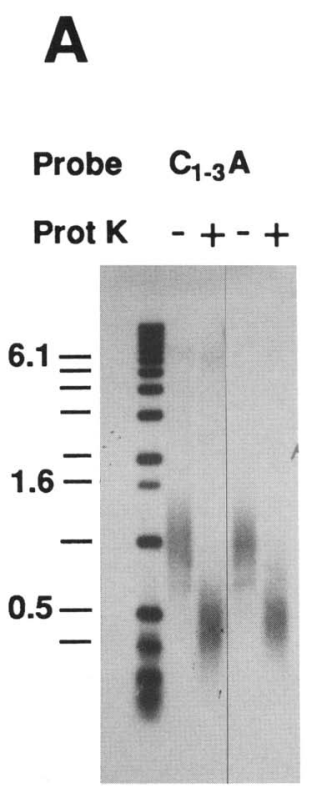

B

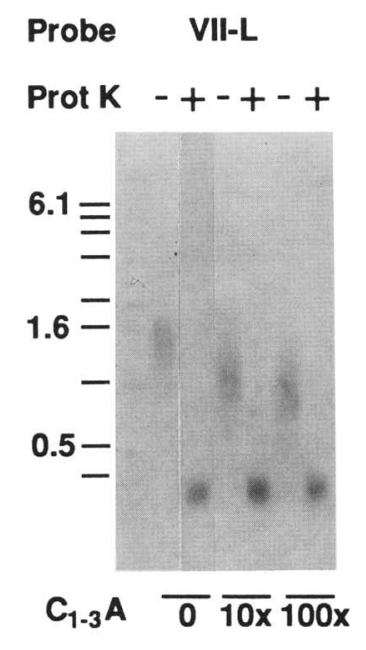

Figure 7. Gel mobility-shift assays on isolated telomeric chromatin. (A) Aliquots of chromatin supernatants prepared from MNase-treated nuclei either were loaded directly onto agarose gels containing ethidium bromide $(-)$ or treated with SDS and proteinase $\mathrm{K}$ prior to loading $1+1$. Two samples each without $1-\mid$ and with $1+\mid$ protease treatment are shown. Molecular weight markers are BRL l-kb ladder. This blot is hybridized with the $\mathrm{C}_{1.3} \mathrm{~A}$ probe. (B) Gel mobility-shift assays of chromatin

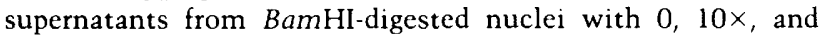
$100 \times$ molar excess of $\mathrm{C}_{1.3} \mathrm{~A}$ competitor DNA added to the nuclei prior to lysis. Duplicate lanes with $(+)$ and without $(-)$ treatment with SDS and proteinase $\mathrm{K}$ are shown. The amount of competitor added to each lane is indicated below the panel. This blot is probed with the unique sequence DNA next to the chromosome VII-L telomere (solid box, Fig. 4B).

for the gel mobility-shift displayed by telosomes had associated with $\mathrm{C}_{1-3}$ A DNA in vivo or in vitro. Gel mobility-shift experiments were performed in the presence of 10- or 100-fold molar excess of cloned $\mathrm{C}_{1-3} \mathrm{~A}$ DNA that was added to nuclei prior to their disruption. Because the $\mathrm{C}_{1-3} \mathrm{~A}$ competitor fragments were similar in length to endogenous telomeres, a $\mathrm{C}_{1.3} \mathrm{~A}$ probe could not be used to analyze these gels. Instead, the competition blots were probed with the unique DNA adjacent to the $\mathrm{C}_{1-3} \mathrm{~A}$ repeats on the modified chromosome VII-L telomere (Fig. 4). Although addition of specific competitor increased the relative mobility of the protein-bound telosomes, $100 \%$ of the detectable chromosome VII-L telosomes still displayed a protein-dependent gel shift in the presence of a 100-fold molar excess of $\mathrm{C}_{1-3} \mathrm{~A}$ DNA (Fig. $7 \mathrm{~B}$ ). When this same blot was probed with $\mathrm{C}_{1-3} \mathrm{~A}$, only a small fraction of the competitor $\mathrm{C}_{1-3} \mathrm{~A}$ fragments were shifted in mobility by in vitro protein binding (data not shown), indicating that this experiment was done under conditions where competitor DNA was in excess over free protein. The fact that some of the telosome-associated proteins were not competed with the specific com- petitor suggested that this complex was formed prior to disruption of the nuclei, providing additional evidence that telomeric sequences are protein bound in vivo. The increased mobility of the shifted complex that was observed in the presence of competitor from $\sim 1.6 \mathrm{~kb}$ to $\sim 1.0 \mathrm{~kb}$ suggested that some protein or proteins were competed away. In many experiments done in the absence of competitor (including the one shown in Fig. 7A), telosomes migrated at $\sim 1.0 \mathrm{~kb}$. Thus, the component of the soluble telosomes that was competed for in this experiment did not appear to copurify with telosomes consistently, suggesting that it was not an integral part of the protein-DNA complex.

The RAP1 protein interacts with yeast telomeres in vitro (Buchman et al. 1988) and in vivo (Conrad et al. 1990; Lustig et al. 1990; Sussel and Shore 1991). To determine whether RAPl protein is present in telosomes, RAP1 antiserum was added to a chromatin supernatant obtained from MNase-digested nuclei. In these experiments, $30-50 \%$ of the telosomes were specifically precipitated by the RAP1 antibody (Fig. 8A, left panel). In contrast, $2-\mu \mathrm{m}$ DNA, which is nucleosomal (Livingston and Hahne 1979; Nelson and Fangman 1979), was not precipitated by the antiserum (Fig. 8A, right panel). No precipitation of telomeric fragments was observed with the preimmune sera (data not shown). This experiment was repeated in the presence of 10- and 100-fold molar excess of $C_{1-3} A$ DNA. In the presence of 100 -fold molar excess of $\mathrm{C}_{1.3} \mathrm{~A}$ DNA, the immunoprecipitation of the chromosome VII-L telomeric fragment was reduced about twofold (Fig. 8B). The fact that competition with the specific competitor was not complete suggested that RAPl was associated with the telosome in nuclei prior to the addition of the specific competitor, indicating that the RAPl protein is a component of telosomes in vivo. The partial competition for the RAP1 binding to the telosome could account for the change in mobility of the protein bound telosomes seen with addition of competitor (Fig. 7B).

\section{Discussion}

Most yeast DNA sequences, including the subtelomeric repeats $\mathrm{X}$ and $\mathrm{Y}^{\prime}$ (Fig. 1), are assembled in nucleosomes. In contrast, the $\mathrm{C}_{1-3} \mathrm{~A}$ repeats at the very ends of yeast chromosomal DNA molecules are assembled in a nonnucleosomal chromatin structure, herein called a telosome. The conclusion that the terminal $\mathrm{C}_{1 \cdot 3} \mathrm{~A}$ repeats are in telosomes comes from studies using two nucleases, MNase and DNase I, and from examination of the protection patterns of both total $\mathrm{C}_{1-3} \mathrm{~A}$ DNA (Figs. 1 and 2) and two individual telomeres, a modified form of the chromosome VII-L telomere (Fig. 4) and the natural end of chromosome I-R (Fig. 5). This conclusion is also supported by gel-retardation studies indicating that $C_{1}$. $3 \mathrm{~A}$ repeats were protein associated prior to disruption of isolated nuclei (Figs. 7 and 8).

Telosomes were found to differ from nucleosomes in several ways. First, telosomes contained about twice as 
Figure 8 Immunoprecipitations of chromatin supernatants with anti-RAPl antiserum. (A) Chromatin supernatants were prepared from nuclei digested with MNase for 2 or $4 \mathrm{~min}$ and immunoprecipitated with a RAP1 antiserum. DNAs were purified from the immunosupernatant $(\mathrm{S})$ and the immunopellet $(\mathrm{P})$, subjected to electrophoresis in a $1 \%$ agarose gel, and blotted. The blot was probed sequentially with $\mathrm{C}_{1-3} \mathrm{~A}$ (left) and $2 \mu \mathrm{m}$ of DNA (right). The molecular weight markers are BRL 1-kb ladder. $(B)$ Chromatin supernatants were prepared from BamHI-digested nuclei with 0, $10 \times$, and $100 \times$ molar excess $\mathrm{C}_{1-3} \mathrm{~A}$ competitor DNA. Chromatin supernatants were immunoprecipitated, and DNAs were purified and prepared as in $A$. The amount of $\mathrm{C}_{1-3} \mathrm{~A}$ competitor DNA is indicated below the panel. The blot was probed with the unique DNA adjacent to the $\mathrm{C}_{1-3} \mathrm{~A}$ tract on the modified chromosome VII-L (solid box, Fig. 4B). Molecular weight markers are BRL $1-\mathrm{kb}$ ladder. This blot was quantified by storage phosphor imaging (Johnston et al. 1990).
A

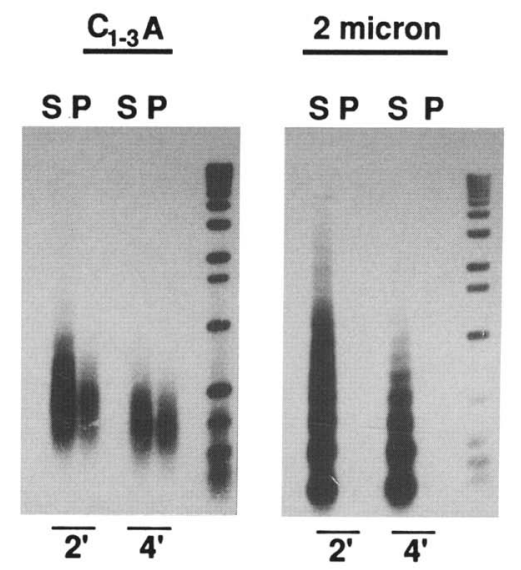

B

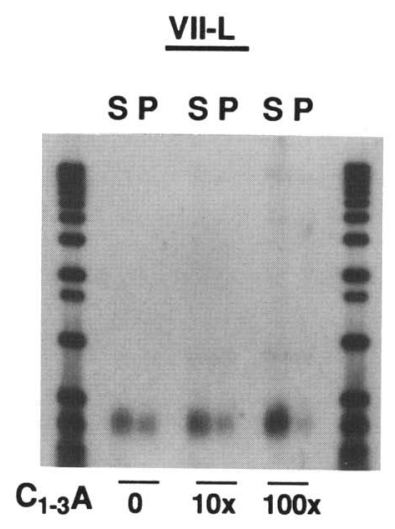

much DNA as nucleosomes (Fig. 4). Second, unlike nucleosomes, telosomes contained a variable amount of DNA (Figs. 1, 2, 4, and 5). Telosomes protected the most distal $245-395 \mathrm{bp}$ of DNA, starting from a point $\sim 50 \mathrm{bp}$ internal to the start of the simple repeats and encompassing the entire terminal tract of $\mathrm{C}_{1 \cdot 3} \mathrm{~A}$ repeats (Fig. 4A). Because the lengths of these terminal tracts vary from telomere to telomere, telosomes from different chromosomes can differ in size by as much as $150 \mathrm{bp}$ of DNA (Figs. 1, 2, and 4). Additional experiments with soluble telosomes indicated that at least some telosomal proteins were not displaced by intercalation of ethidium bromide (J.H.Wright and V.A. Zakian, unpubl.); in contrast, nucleosomes are dissociated by ethidium bromide (McMurray and van Holde 1986). Although these data do not preclude the possibility that histones participate in forming telosomes, they do demonstrate that conventional nucleosomes do not continue out to the very ends of chromosomal DNA molecules.

In contrast to internucleosomal linker regions, the region that links the telosome to adjacent nucleosomal DNA contains a strong hypersensitive site for DNase I (Figs. 2, 4, and 5). The DNase I hypersensitivity of these sites is protein dependent in that the $\mathrm{C}_{1-3} \mathrm{~A}$ unique DNA boundary was not a preferred site for DNase I in naked DNA (Figs. 2, 4, and 5). Proximity to the telomere is the cause of this hypersensitivity. This conclusion was reached by comparing the digestion patterns of very similar DNA sequences located telomerically and subtelomerically on two different chromosomes (Fig. 5). The only major difference in the deduced chromatin structure of a 1.3-kb region present on both chromosomes was a strong DNase I hypersensitive site that was observed only on chromosome I where this sequence was adjacent to a telosome (marked by an arrow in Fig. 5A). Another hypersensitive site was observed with both the $\mathrm{C}_{1-3} \mathrm{~A}$ and $\mathrm{Y}^{\prime}$ probes, generating a band at $\sim 6.5 \mathrm{~kb}$ (Fig. 2). The size of this DNA fragment was approximately the same as the unit length of the $\mathrm{Y}^{\prime}$ element. This result is con- sistent with the possibility that $\mathrm{Y}^{\prime}$ junctions are also hypersensitive to DNase I. In yeast, DNase I hypersensitive sites are found flanking centromeres (Bloom and Carbon 1982), at $A R S$ s (Thoma et al. 1984; Brown et al. 1991), and at other sites bound by nonhistone proteins such as at the $G A L 1,10$ upstream activating sequence (UAS) (Lohr 1984). Thus, DNase I hypersensitivity at telomeres and at other genomic sites may mark transition points between different chromatin structures.

A GATC site within the region containing the DNase I hypersensitive site on the modified form of chromosome VII-L was $100 \%$ accessible in vivo to methylation by $E$. coli dam methylase when the enzyme was expressed in yeast. In contrast, a GATC site $200 \mathrm{bp}$ internal to this accessible site, located within the $U R A 3$ gene, was relatively inaccessible to the methylase (Fig. 6). In fact, this site was less accessible to dam methylase at the telomere than when it was located at internal sites on the chromosome (Fig. 6). When the nucleosome-telosome linker region contained a recognition site for $B a m H I$, the site was BamHI accessible in nuclei at $>80 \%$ of telomeres (J.H. Wright and V.A. Zakian, unpubl.). The accessibility of this linker region to in vivo methylation on both DNA strands and to digestion by DNase I, MNase, and BamHI in nuclei suggests that this region is not protein associated or that it protrudes from the protein-DNA complex.

Because the telosome-nucleosome linker region is nuclease accessible, telosomes can be released from chromosomes as protein-DNA complexes (Figs. 7 and 8). The RAPl protein was identified as one component of solubilized telosomes (Fig. 8), corroborating our previous results demonstrating that RAPl is associated with isolated termini from a short, multicopy linear plasmid (Conrad et al. 1990). Telomeres in yeast and other organisms have been shown to associate with the synaptonemal complex in meiosis (Moens and Pearlman 1990) and with the nuclear envelope in interphase nuclei (e.g., Agard and Sadat 1983; Rawlins et al. 1991). In addition to 
its binding to telomeres, the RAP1 protein fractionates with the nuclear scaffold and can mediate loop formation between noncontiguous RAP1-binding sites in vitro (Hofmann et al. 1989; Cardenas et al. 1990). Moreover, RAP1 protein has been shown by immunofluorescence to colocalize with the termini of meiotic chromosomes (F. Klein and S. Gasser, pers. comm.). Thus, RAP1 is a good candidate for a protein that mediates telomere associations both with other telomeres and with the nuclear scaffold. Although $30-50 \%$ of the telomeres had bound RAPl as shown by specific immunoprecipitation with a RAP1 antiserum (Fig. 8), only a small fraction of the RAP1 protein copurified with telomeric chromatin (J.H. Wright and V.A. Zakian, unpubl.). Thus, most of the RAP1 protein is either free in the cell, associated with some of the many other RAPl-binding sites in yeast DNA (Buchman et al. 1988), or sequestered in structures such as the nuclear scaffold (Cardenas et al. 1990).

Some of the telosomal proteins detected in the gel mobility-shift assay were not competed away from the endogenous telomeric DNA by 100 -fold molar excess of cloned $\mathrm{C}_{1-3} \mathrm{~A}$ DNA added prior to nuclear lysis (Fig. $7 \mathrm{~B}$ ). This result is consistent with the interpretation that the complex was formed before the competitor DNA was added, that is, in vivo. The salt-stable Oxytricha terminus-binding proteins also do not readily exchange with added telomeric DNA ends /Gottschling and Zakian 1986; Raghuraman and Cech 1989). The low exchange rate exhibited by some of the yeast telosomal proteins suggests that the yeast telosome may contain analogs of the Oxytricha terminus-binding proteins. This possibility is strengthened by preliminary data indicating that the solubilized telosomes from yeast are more salt stable than nucleosomes (J.H. Wright and V.A. Zakian, unpubl.).

In summary, we analyzed the chromatin structures of the $X$ and $Y^{\prime}$ elements found in subtelomeric regions of yeast chromosomes and of the simple repeats at the very ends of chromosomal DNA molecules. $\mathrm{X}$ and $\mathrm{Y}^{\prime}$ are organized in nucleosomes, as is the $U R A 3$ gene when it is moved next to a yeast telomere. Proximity to the telomere has very little effect on the chromatin structure of adjacent DNA sequences as seen with these nucleases: $U R A 3$ has the same chromatin structure at the telomere as at other sites in the genome, and a region $1.6 \mathrm{~kb}$ from the end of chromosome I has the same chromatin structure as a very similar region $6.5 \mathrm{~kb}$ from the end of chromosome VIII. The $\mathrm{C}_{1-3} \mathrm{~A}$ repeats at the very ends of yeast chromosome are organized into telosomes that can be released as protein-DNA complexes by the actions of several nucleases. RAPl protein is one component of soluble telosomes. Experiments similar to those described here for RAPl can be carried out to determine whether other proteins that bind to yeast telomeric repeats in vitro (Liu and Tye 1991) are present in the telosome. It will also be of interest to examine the structure of telosomes in mutant strains (e.g., see Lustig and Petes 1986; Lundblad and Szostak 1989; Sussel and Shore 1990) and under conditions (Runge and Zakian 1989; Conrad et al. 1990) where telomere structure or function is altered.

\section{Materials and methods}

Yeast strains

Most experiments were carried out in strain IW2 (MATa lys5 ura3 $\Delta::$ hisG leu2-3,112 trp1 $::$ hisG ade2 ade5 can1 cyh2 prb1 $\Delta::$ hisG). To make JW2, the protease B gene PRB1 (Moehle et al. 1987) was deleted and replaced with the bacterial hisG sequence in the yeast strain DM30 (Runge et al. 1991) by use of previously published methods (Alani et al. 1987); URA3 was then inserted on the left telomere of chromosome VII (Gottschling et al. 1990) as diagramed in Figure 3. The plasmid used to modify chromosome VII-L was similar to the VII-L URA3-TEL plasmid described in Gottschling et al. (1990), with an additional $60 \mathrm{bp}$ of sequence between the $U R A 3$ gene and the $\mathrm{C}_{1-3}$ A DNA as described in Conrad et al. (1990). This $60 \mathrm{bp}$ contains a copy of the lac operator, as well as a concatamer of $\mathrm{BamHI}$ sites. All yeast transformations were done according to Ito et al. (1983).

The strains used for analysis of the telomeric regions of chromosomes I and VIII were, respectively, YS12 $\Delta$ UL $\Delta$ and YS1 $1 \Delta U L \Delta$. These strains were derived from YS18-2 (MAT $\alpha$ his3-11 his3-15 leu2-3 leu2-112 ura3-432 ura3-601 can1 ${ }^{\mathrm{R}}$ pho10:URA3; obtained from W. Horz). YS18-2 was modified by deleting a 5-kb EcoRI fragment containing PHO12, to produce YS12 1 UL $\Delta$, or containing PHO11, to produce YS11 $1 \Delta L \Delta$. The PHO11 and PHO12 deletions were obtained by transforming YS18-2 with a DNA fragment containing the HIS3 gene flanked by short stretches of DNA found at both the PHO11 and PHO12 loci. The fragment used for the transformation was isolated from pPHOl1, a plasmid with an insert containing a 5-kb EcoRI fragment of the PHO11 gene lobtained from W. Horz; Venter and Horz 1989). A 4.6-kb DraI-KpnI fragment within the 5-kb EcoRI insert in pPHOll was replaced with a $1.8 \mathrm{-kb}$ BamHI fragment containing the HIS 3 gene. The resulting $2.2-\mathrm{kb} E c o \mathrm{RI}$ fragment was used to transform YS18-2. Transformants were screened by Southern blotting for the PHO11::HIS3 deletion/ insertion or the PHO12::HIS3 deletion/insertion. These strains also contained a third, unidentified locus that hybridized to the probe used in the chromatin mapping analyses. This cross-hybridizing locus was deleted in both strains by transformation with a $2.7-\mathrm{kb}$ fragment containing a $2.2 \mathrm{~kb}$ Xhol-Sall fragment of the LEU2 gene flanked by 230-bp BclI-HindIII and 200-bp KpnI-EcoRI fragments subcloned from pPHO11. The result of these manipulations was the construction of two strains in which the 230-bp HindIII-KpnI fragment of pPHO11 hybridized uniquely to either the PHO11 or PHO12 locus. The distance between PHO11 and the end of the chromosome in YS12 2 ULA is not large enough to contain a $Y^{\prime}$ element. The lack of $Y^{\prime}$ on chromosome I-R was confirmed directly in YS18-2 (Venter and Horz 1989). Two X probes hybridized to the terminal $10 \mathrm{~kb}$ of chromosome I-R in a strain called AB972 (de Steensma et al. 1989; H.Y. Steensma, pers. comm.). In both YS12 $\Delta$ UL $\Delta$ and YS1 $1 \Delta \mathrm{UL} \Delta$, the right end of chromosome I had the same restriction map as in AB972. Thus, the right end of chromosome I and the PHO12 end of chromosome VIII in JW2 both contain at least some sequences from the $\mathrm{X}$ element.

The yeast strains used for the dam methylase experiments were UCC1023 (MATa ura3-52 lys2-801:dam ${ }^{+}:$LYS2 ade2-101 trp1- $\Delta 1$ his $3 \Delta 200$ ) and UCC1021 (UCC1023 with adh4::URA3-TEL). In these strains the $E$. coli dam methylase gene was integrated at the LYS2 gene on yeast chromosome II-R as described (Gottschling 1992), where it is expressed constitutively, presumably from a fortuitous promoter within the bacterial DNA. The dam methylase gene was isolated as a $1.5-\mathrm{kb}$ HindIII-PvuII fragment from pMFHl (Hoekstra and Malone 1985). 


\section{Preparation of yeast chromatin and DNA}

Nuclease digestion of chromatin was carried out in nuclei isolated by modification of methods described in Kenna et al. (1980). Cells were grown to $2 \times 10^{7}-1 \times 10^{8} \mathrm{cells} / \mathrm{ml}$ at $30^{\circ} \mathrm{C}$ in YEPD (Zakian and Scott 1982). Cells were washed once with water, once with SCE- 60 (1 M sorbitol, $0.1 \mathrm{M}$ sodium citrate, 60 mM EDTA at pH 7.5), resuspended in $25 \mathrm{ml}$ of SCE- 60 with 14 $\mathrm{mM} \beta$-mercaptoethanol and $0.5 \mathrm{mg} / \mathrm{ml} \mathrm{Zymolyase-100T} \mathrm{(ICN),}$ and incubated for $30 \mathrm{~min}$ at $30^{\circ} \mathrm{C}$. Spheroplasts were collected by centrifugation and washed with $40 \mathrm{ml}$ of cold SPC $(1 \mathrm{M}$ sorbitol, $20 \mathrm{~mm}$ PIPES at pH 6.3, $10 \mathrm{mM} \mathrm{CaCl}_{2}, 1 \mathrm{~mm}$ PMSF, $1 \mathrm{~mm}$ iodoacetic acid). The remaining steps of the procedure were done at $4^{\circ} \mathrm{C}$. The spheroplast pellet was resuspended in $2 \mathrm{ml}$ of SPC, added to $40 \mathrm{ml}$ of FPC $(9 \%$ Ficoll, $20 \mathrm{~mm}$ PIPES at pH 6.3, $10 \mathrm{mM} \mathrm{CaCl}_{2}, 1 \mathrm{~mm}$ PMSF, $1 \mathrm{~mm}$ iodoacetic acid), and mixed by inversion. Cell lysis was allowed to occur for $15 \mathrm{~min}$ on ice. To pellet nuclei, the lysate was centrifuged at $13,000 \mathrm{rpm}$ in a Sorvall SS-34 rotor for $20 \mathrm{~min}$ at $4^{\circ} \mathrm{C}$. DNA was isolated for the naked DNA controls as described in Runge et al. (1989).

\section{Nuclease assays}

For chromatin digestions, nuclear pellets were washed in $\sim 10$ volumes of PC $\left(50 \mathrm{~mm}\right.$ PIPES at $\mathrm{pH} 6.3,0.1 \mathrm{mM} \mathrm{CaCl}_{2}, 75 \mathrm{~mm}$ $\mathrm{NaCl}, 6 \mathrm{mM} \mathrm{MgCl}$ ) and resuspended at $7.5 \times 10^{9}$ cells $/ \mathrm{ml}$ in $\mathrm{PC}+6 \mathrm{mM} \mathrm{CaCl}_{2}$ for MNase assays, and in PC for DNase I assays. Nuclei were aliquoted into $1.5-\mathrm{ml}$ microtubes at 200 $\mu \mathrm{l} /$ tube. MNase $(1 \mathrm{U} / 100 \mu \mathrm{l}$; Sigma) or DNase I $(0.2 \mu \mathrm{g} / 100 \mu \mathrm{l}$; Worthington) was added on ice, and the tubes were incubated at $37^{\circ} \mathrm{C}$ for varying amounts of time (see figure legends). Reactions were stopped with one-tenth volume of SE ( $2 \%$ Sarkosyl, $0.4 \mathrm{M}$ EDTA) and $50 \mu \mathrm{g}$ of proteinase $\mathrm{K}$ and incubated overnight at $37^{\circ} \mathrm{C}$. DNA was extracted and precipitated as for the naked DNA controls. Assays on naked DNAs were performed in 200 $\mu \mathrm{l}$ of $\mathrm{PC}+50 \mathrm{mM} \mathrm{CaCl}_{2}$ for $\mathrm{MNase}$ or $\mathrm{PC}+50 \mathrm{mM} \mathrm{MgCl}_{2}$ for DNase I; 0.5 units of MNase or $10 \mathrm{ng}$ of DNase I was added per tube, and the samples were incubated for varying times as indicated in the figure legends. The digestions with both nucleases on naked DNA were done at higher divalent ion concentration as a result of chelating activity that copurified with the DNA. The higher calcium concentration decreased the rate of cleavage by MNase yet did not affect its specificity (data not shown).

\section{Assay for in vivo methylation}

DNA was isolated from UCC1021 or UCC1023 cells that were grown to stationary phase in YEPD. DNA was digested by the appropriate restriction enzymes, separated by electrophoresis on a $1.5 \%$ agarose gel, transferred, cross-linked to a nylon membrane by UV irradiation, and hybridized to a $0.7-\mathrm{kb}$ EcoRVSmaI URA3 DNA fragment (Rose et al. 1984) that had been labeled with digoxigenin-dUTP according to the manufacturer's protocol (Boehringer Mannheim). X-ray film was used to detect the probe using the Genius* Lumi-Phos Kit (Boehringer Mannheim).

\section{Solubilization of chromatin}

Nuclei were isolated and treated with nuclease as described above, except the reactions were stopped with one-tenth volume of $0.5 \mathrm{M}$ EDTA at $\mathrm{pH} 7.5$ and diluted 2.5 -fold with binding buffer [10 $\mathrm{mm}$ Tris at $\mathrm{pH} 7.5,10 \mathrm{mM} \mathrm{MgCl}_{2}, 60 \mathrm{mM} \mathrm{NaCl}, 0.1$ mM DTT, $0.1 \mathrm{~mm}$ EDTA, $0.1 \mathrm{mM}$ PMSF, $1 \mu \mathrm{g} / \mathrm{ml}$ of leupeptin, 1 $\mu \mathrm{g} / \mathrm{ml}$ of pepstatin, $10 \mu \mathrm{g} / \mathrm{ml}$ of $\alpha-N$-toluene-p-sulphonyl-L-argi- nine-methyl-ester-hydrochloride (TAME)]. Sterile glass beads $(500 \mu \mathrm{l} ; 425-600 \mu \mathrm{m}$ in diameter, Sigma) were added to $500 \mu \mathrm{l}$ of nuclei in $1.5-\mathrm{ml}$ microtubes. Tubes were shaken at $4^{\circ} \mathrm{C}$ for 30 min in an Eppendorf model 5432 tube mixer. The bottoms of the tubes were punctured with a needle, and the liquid spun into new tubes. The disrupted nuclei were centrifuged at $10,000 \mathrm{~g}$ for $5 \mathrm{~min}$. The supernatant contained the soluble chromatin. This method is an adaptation of procedures developed by M. Saunders and K. Bloom (pers. comm.). For the BamHI-digested chromatin supernatants, no other nuclease digestion was done; $B a m H I$ digestion was done at $4^{\circ} \mathrm{C}$ during the nuclear lysis with glass beads with 500 units of enzyme (NEB). The $C_{1-3} A$ competitor DNA was a $7.5 \mathrm{~kb}$ Sall fragment from the plasmid pYLPV (R. Wellinger, A. Wolf, and V.A. Zakian, in prep.), which contains two $\sim 300 \mathrm{bp}$ tracts of $\mathrm{C}_{1-3} \mathrm{~A}$ DNA cloned from natural yeast telomeres by the methods described in Wang and Zakian (1990). The competitor was added to the nuclei prior to their disruption. Each $\sim 300$-bp tract was considered the molar equivalent of a yeast telomere.

\section{Agarose gel electrophoresis and hybridization methods}

All DNA samples were analyzed on $1 \%$ agarose gels fultraPURE, BRL) containing $1 \mu \mathrm{g} / \mathrm{ml}$ of ethidium bromide. Electrophoresis was done in TAE buffer $(40 \mathrm{~mm}$ Tris-acetate, $1 \mathrm{~mm}$ $\mathrm{Na}_{2}$ EDTA, $5 \mathrm{~mm}$ sodium acetate at $\mathrm{pH} 7.9$ ) in a horizontal submarine gel apparatus. All Southern blots were done according to previously described methods (Runge and Zakian 1989).

All probes, including the $\mathrm{C}_{1-3} \mathrm{~A}$ oligonucleotide, were radioactively labeled using the random primer procedure (Feinberg and Vogelstein 1983). The X probe was a $\sim 600$-bp EcoRI-EcoRV fragment subcloned from the plasmid pYP1-L3 (Louis and Haber 1991) obtained from E. Louis. This X probe was found to hybridize to all chromosomes in all strains tested (E. Louis and J. Haber, pers. comm.). The $\mathrm{Y}^{\prime}$ probe was a 600 -bp $\mathrm{KpnI}$ fragment from a portion of $\mathrm{Y}^{\prime}$ distal to the $X$ hol site, isolated from YRp131B (Chan and Tye 1983). The $C_{1-3} A$ probe was a pair of complementary 39-bp oligonucleotides containing 35 bp of $C_{1}$. ${ }_{3} \mathrm{~A}$ sequence, whose exact sequence is based on that of a cloned yeast telomere (Runge and Zakian 1990). In JW2, 80\% of the $\mathrm{C}_{1-3} \mathrm{~A}$ hybridization was to terminal $\mathrm{C}_{1-3} \mathrm{~A}$ tracts, and most telomeres possessed a single $\mathrm{Y}^{\prime}$ element as determined by quantifying hybridization signals to genomic Southern blots with $\mathrm{Y}^{\prime}$ and $\mathrm{C}_{1 \cdot 3} \mathrm{~A}$ probes. These quantifications showed that $\sim 80 \%$ of the $\mathrm{C}_{1.3} \mathrm{~A}$ hybridization and $\sim 70 \%$ of the $\mathrm{Y}^{\prime}$ hybridization was to a $1.3-\mathrm{kb}$ Xhol fragment derived from the end of $\mathrm{Y}^{\prime}$ telomeres.

The URA3 probe was a 100-bp PstI-RsaI fragment from the $5^{\prime}$ end of the URA3 gene (Rose et al. 1985). The probe for the unique DNA immediately adjacent to the $\mathrm{C}_{1-3} \mathrm{~A}$ tract on the modified chromosome VII-L telomere was a pair of complementary 60-bp oligonucleotides containing the lac operator (Conrad et al 1990). The probe used to map chromosome I-R and chromosome VIII was a 230-bp HindIII-KpnI probe subcloned from pPHO11 (Venter and Horz 1989). The $2-\mu \mathrm{m}$ probe was a $1.3-\mathrm{bp}$ HindIII fragment isolated from recombinant DNA plasmid CV20 (Jayaram et al. 1983).

\section{Gel mobility-shift assays}

Chromatin supernatants were subdivided into aliquots in duplicate at $40 \mu \mathrm{l}$ per tube on ice. Four microliters of $1 \%$ SDS and $10 \mu \mathrm{g}$ of proteinase $\mathrm{K}$ were added to one, and then one or both was incubated at $37^{\circ} \mathrm{C}$ for $20 \mathrm{~min}$. Gel dye and glycerol were added just prior to loading the gel. The gels were run at 10.7 $\mathrm{V} / \mathrm{cm}$ for $3 \mathrm{hr}$ using the electrophoresis conditions described above. 


\section{Immunoprecipitations}

Chromatin supernatant $(250 \mu \mathrm{l})$ was mixed with $16 \mu \mathrm{l}$ of RAP1 antiserum or with preimmune serum (Conrad et al. 1990) and incubated on ice. Protein A-Sepharose $(50 \mu \mathrm{l})$ was added in two aliquots for a total incubation time of $60 \mathrm{~min}$. The beads were washed four times with binding buffer. Material retained by the beads was eluted with $1 \%$ SDS at $65^{\circ} \mathrm{C}$. DNAs from both supernatant and pellet fractions were purified for DNA isolated for naked DNA controls, except that $10 \mu \mathrm{g}$ of tRNA was added as carrier prior to ethanol precipitation. The samples were resuspended in TE $+2 \mu \mathrm{g}$ of RNase A and subjected to standard gel electrophoresis and Southern blotting.

\section{Acknowledgments}

We thank W. Horz for the PHO clones and strains, E. Jones for the $P R B 1$ gene, and E. Louis for the $\mathrm{X}$ clone. We also thank $\mathrm{E}$. Louis, J. Haber, and H.Y. Steensma for sharing unpublished data. We are grateful to Tina Quinton for the preliminary work on mapping of chromosome I-R. We thank Mark Groudine, and members of our laboratory for critical comments on the manuscript. This work was supported by National Institutes of Health grants GM43265 to V.A.Z. and GM43893 to D.E.G. J.H.W. is supported in part by The Molecular Training Program in Cancer Research training grant through the Department of Pathology, University of Washington.

The publication costs of this article were defrayed in part by payment of page charges. This article must therefore be hereby marked "advertisement" in accordance with 18 USC section 1734 solely to indicate this fact.

\section{References}

Agard, D.A. and J.W. Sadat. 1983. Three-dimensional architecture of a polytene nucleus. Nature 302: 676-681.

Alani, E., L. Cao, and N. Kleckner. 1987. A method for gene disruption that allows repeated use of URA3 selection in the construction of multiply disrupted yeast strains. Genetics 116: $541-545$.

Aparicio, O.M., B.L. Billington, and D.E. Gottschling. 1991. Modifiers of position effect are shared between telomeric and silent mating-type loci in S. cerevisiae. Cell 66: 12791287.

Berman, J., C.Y. Tachibana, and B.-K. Tye. 1986. Identification of a telomere binding activity from yeast. Proc. Natl. Acad. Sci. 83: 3713-3717.

Bloom, K.S. and J. Carbon. 1982. Yeast centromere DNA is a unique and highly ordered structure on chromosomes and small circular minichromosomes. Cell 29: 305-317.

Bostian, K.A., J.M. Lemire, and H.O. Halvorson. 1983. Physiological control of repressible acid phosphatase gene transcripts in Saccharomyces cerevisiae. Mol. Cell. Biol. 3: 839853.

Brown, J.A., S.G. Holmes, and M.M. Smith. 1991. The chromatin structure of Saccharomyces cerevisiae autonomously replicating sequences changes during the cell division cycle. Mol. Cell. Biol. 11: 5301-5311.

Buchman, A.R., W.J. Kimmerly, J. Rine, and R.D. Kornberg. 1988. Two DNA-binding factors recognize specific sequences at silencers, upstream activating sequences, autonomously replicating sequences, and telomeres in Saccharomyces cerevisiae. Mol. Cell. Biol. 8: 210-225.

Budarf, M.L. and E.H. Blackburn. 1986. Chromatin structure of the telomeric region and $3^{\prime}$-nontranscribed spacer of Tet- rahymena ribosomal RNA genes. I. Biol. Chem. 261: 363369.

Button, L.L. and C.R. Astell. 1986. The Saccharomyces cerevisiae chromosome III left telomere has a type X, but not a type $\mathrm{Y}^{\prime}$, ARS region. Mol. Cell. Biol. 6: 1352-1356.

Cardenas, M.E., T. Laroche, and S.M. Gasser. 1990. The composition and morphology of yeast nuclear scaffolds. $J$. Cell Sci. 96: 439-450.

Chan, C.S.M. and B.-K. Tye. 1983. Organization of DNA sequences and replication origins at yeast telomeres. Cell 33: $563-573$.

Chiou, S. and E.H. Blackburn. 1981. Non-nucleosomal packaging of a tandemly repeated DNA sequence at termini of extrachromosomal DNA coding for rRNA in Tetrahymena. Proc. Natl. Acad. Sci. 78: 2263-2267.

Conrad, M.N., J.H. Wright, A.J. Wolf, and V.A. Zakian. 1990. RAP1 interacts with yeast telomeres in vivo: Overproduction alters telomere structure and decreases chromosome stability. Cell 63: 739-750.

Edwards, C.A. and R.A. Firtel. 1984. Site-specific phasing in the chromatin of the rDNA in Dictyostelium discoideum. $/$. Mol. Biol. 180: 73-90.

Feinberg, A.P. and B. Vogelstein. 1983. A technique for radiolabelling DNA restriction fragments to high specific activity. Anal. Biochem. 132: 6-13.

Gottschling, D.E. and T.R. Cech. 1984. Chromatin structure of the molecular ends of Oxytricha macronuclear DNA: Phased nucleosomes and a telomeric complex. Cell 38: 501510 .

Gottschling, D.E. and V.A. Zakian. 1986. Telomere proteins: Specific recognition and protection of the natural termini of Oxytricha macronuclear DNA. Cell 47: 195-205.

Gottschling, D.E., O.M. Aparicio, B.L. Billington, and V.A. Zakian. 1990. Position effect at S. cerevisiae telomeres: Reversible repression of Pol II transcription. Cell 63: 751-762.

Gross, D.S. and W.T. Garrard. 1988. Nuclease hypersensitive sites in chromatin. Annu. Rev. Biochem. 57: 159-197.

Hoekstra, M.F. and R.E. Malone. 1985. Expression of the Escherichia coli dam methylase in Saccharomyces cerevisiae: Effect of in vivo adenine methylation on genetic recombination and mutation. Mol. Cell. Biol. 5: 610-618.

Hofmann, J.F-X., T. Laroche, A.H. Brand, and S.M. Gasser. 1989. RAP-1 factor is necessary for DNA loop formation in vitro at the silent mating type locus HML. Cell 57: 725-737.

Ito, H., Y. Jukuda, K. Murata, and A. Kimura. 1983. Transformation of intact yeast cells treated with alkali cations. $/$. Bacteriol. 153: 163-168.

Jayaram, M., Y.-Y. Li, and J.R. Broach. 1983. The yeast plasmid $2 \mu$ circle encodes components required for its high copy propagation. Cell 34: 95-104.

Johnston, R.F., S.C. Pickett, and D.L. Barker. 1990. Autoradiography using storage phosphor technology. Electrophoresis 11: $355-360$

Kenna, M., E. Amaya, and K. Bloom. 1988. Selective excision of the centromere chromatin complex from Saccharomyces cerevisiae. I. Cell Biol. 107: 9-15.

Liu, Z. and B.K. Tye. 1991. A yeast protein that binds to vertebrate telomeres and conserved yeast telomeric junctions. Genes \& Dev. 5: 49-59.

Livingston, D.M. and S. Hahne. 1979. Isolation of a condensed, intracellular form of the 2- $\mu \mathrm{m}$ DNA plasmid of Saccharomyces cerevisiae. Proc. Natl. Acad. Sci. 76: 3727-3731.

Lohr, D. 1984. Organization of the GAL1-GAL10 intergenic control region chromatin. Nucleic Acids Res. 12: 84578474.

Lohr, D. and G. Ide. 1979. Comparison of the structure and 
transcriptional capability of growing phase and stationary yeast chromatin: A model for reversible gene activation. $\mathrm{Nu}$ cleic Acids Res. 6: 1909-1927.

Louis, E.J. and J.E. Haber. 1990. The subtelomeric $\mathrm{Y}^{\prime}$ repeat family in Saccharomyces cerevisiae: An experimental system for repeated sequence evolution. Genetics 124: 533545 .

- 1991. Evolutionarily recent transfer of a group I mitochondrial intron to telomere regions in S. cerevisiae. Curr. Genet. (in press).

Lucchini, R., U. Pauli, R. Braun, T. Koller, and J.M. Sogo. 1987. Structure of the extrachromosomal ribosomal RNA chromatin of Physarum polycephalum. J. Mol. Biol. 196: 829-843.

Lundblad, V. and J.W. Szostak. 1989. A mutant with a defect in telomere elongation leads to senescence in yeast. Cell 57: 633-643.

Lustig, A.J. and T.D. Petes. 1986. Identification of yeast mutants with altered telomere structure. Proc. Natl. Acad. Sci. 83:1398-1402.

Lustig, A.J., S. Kurtz, and D. Shore. 1990. Involvement of the silencer and UAS binding protein in regulation of telomere length. Science 25: 549-553.

McMurray, C.T. and K.E. van Holde. 1986. Binding of ethidium bromide causes dissociation of the nucleosome core particle. Proc. Natl. Acad. Sci. 83: 8472-8476.

Moehle, C.M., R. Tizard, S.K. Lemmon, J. Smart, and E.W. Jones. 1987. Protease B of the lysosomelike vacuole of the yeast Saccharomyces cerevisiae is homologous to the subtilisin family of serine proteases. Mol. Cell. Biol. 7:43904399.

Moens, P.B. and R.E. Pearlman. 1990. Telomere and centromere DNA are associated with the cores of meiotic prophase chromosomes. Chromosoma 100: 8-14.

Nedospasov, S.A. and G.P. Georgiev. 1980. Non-random cleavage of SV40 DNA in the compact minichromosome and free in solution by micrococcal nuclease. Biochem. Biophys. Res. Commun. 92: 532-539.

Nelson, R.G. and W.L. Fangman. 1979. Nucleosome organization of the yeast 2- $\mu \mathrm{m}$ DNA plasmid: A eukaryotic minichromosome. Proc. Natl. Acad. Sci. 76: 6515-6519.

Price, C.M. 1990. Telomere structure on Euplotes crassus: Characterization of DNA-protein interactions and isolation of a telomere-binding protein. Mol. Cell. Biol. 10: 34213431 .

Price, C.M. and T.R. Cech. 1987. Telomeric DNA-protein interactions of Oxytricha macronuclear DNA. Genes \& Dev. 1: 783-793.

1989. Properties of the telomeric DNA-binding protein from Oxytricha nova. Biochemistry 28: 769-774.

Raghuraman, M.K. and T.R. Cech. 1989. Assembly and selfassociation of Oxytricha telomeric nucleoprotein complexes. Cell 59: 719-728.

Rawlins, D.J., M.I. Highett, and P.J. Shaw. 1991. Localization of telomeres in plant interphase nuclei by in situ hybridization and 3D confocal microscopy. Chromosoma 100: 424 431 .

Rose, M., P. Grisafi, and D. Botstein. 1984. Structure and function of the yeast URA3 gene: Expression in Escherichia coli. Gene 29: 113-124.

Runge, K.W. and V.A. Zakian. 1989. Introduction of extra telomeric DNA sequences into Saccharomyces cerevisiae results in telomere elongation. Mol. Cell. Biol. 9: 1488-1497.

- 1990. Properties of the transcriptional enhancer in Saccharomyces cerevisiae telomeres. Nucleic Acids Res. 18: $1783-1787$.

Runge, K.W., R.J. Wellinger, and V.A. Zakian. 1991. Effects of excess centromeres and telomeres on chromosome loss rates. Mol. Cell. Biol. 11: 2919-2928.

Shampay, J., J.W. Szostak, and E.H. Blackburn. 1984. DNA sequences of telomeres maintained in yeast. Nature 310: 154 157.

Shore, D. and K. Nasmyth. 1987. Purification and cloning of a DNA binding protein from yeast that binds to both silencer and activator elements. Cell 51: 721-732.

Steensma, H.Y., P. de Jonge, A. Kaptein, and D.B. Kaback. 1989. Molecular cloning of chromosome I DNA from Saccharomyces cerevisiae: Localization of a repeated sequence containing an acid phosphatase gene near a telomere of chromosome I and chromosome VIII. Curr. Genet. 16: 131-137.

Sussel, L. and D. Shore. 1991. Separation of transcriptional activation and silencing functions of the RAPl-encoded repressor/activator protein 1 : Isolation of viable mutants affecting both silencing and telomere length. Proc. Natl. Acad. Sci. 88: 7749-7753.

Thoma, F. 1986. Protein-DNA interactions and nuclease-sensitive regions determine nucleosome positions on yeast plasmid chromatin. J. Mol. Biol. 190: 177-190.

Thoma, F., L.W. Bergman, and R.T. Simpson. 1984. Nuclease digestion of circular TRP1 ARS1 chromatin reveals positioned nucleosomes separated by nuclease sensitive regions. J. Mol. Biol. 177: 715-733.

Thomas, I.O. and V. Furber. 1976. Yeast chromatin structure. FEBS Lett. 66: 274-280.

van Holde, K.E. 1988. Chromatin (ed. A. Rich). Springer-Verlag, New York.

Venter, U. and W. Horz. 1989. The acid phosphatase genes PHO10 and PHO11 in S. cerevisiae are located at the telomeres of chromosomes VIII and I. Nucleic Acids Res. 17: 1353-1369.

Walmsley, R.W., C.S.M. Chan, B.-K. Tye, and T.D. Petes. 1984. Unusual DNA sequences associated with the ends of yeast chromosomes. Nature 310: 157-160.

Walton, J.D., C.E. Paquin, K. Kaneko, and V.M. Williamson. 1986. Resistance to antimycin $A$ in yeast by amplification of ADH4 on a linear, $42-\mathrm{kb}$ palindromic plasmid. Cell 46: $857-$ 863.

Wang, S.S. and V.A. Zakian. 1990. Sequencing of S. cerevisiae telomeres cloned using T4 DNA polymerase reveals two domains. Mol. Cell. Biol. 10: 4415-4419.

Wu, C. 1980. The $5^{\prime}$ ends of Drosophila heat shock genes in chromatin are hypersensitive to DNase I. Nature 286: 854 860.

Zakian, V.A. 1989. Structure and function of telomeres. Annu. Rev. Genet. 23: 579-604.

Zakian, V.A. and H.M. Blanton. 1988. Distribution of telomereassociated sequences on natural chromosomes in Saccharomyces cerevisiae. Mol. Cell. Biol. 8: 2257-2260.

Zakian, V.A. and J.F. Scott. 1982. Construction, replication, and chromatin structure of TRP1 RI circle, a multi-copy synthetic plasmid derived from Saccharomyces cerevisiae chromosomal DNA. Mol. Cell. Biol. 2: 221-232. 


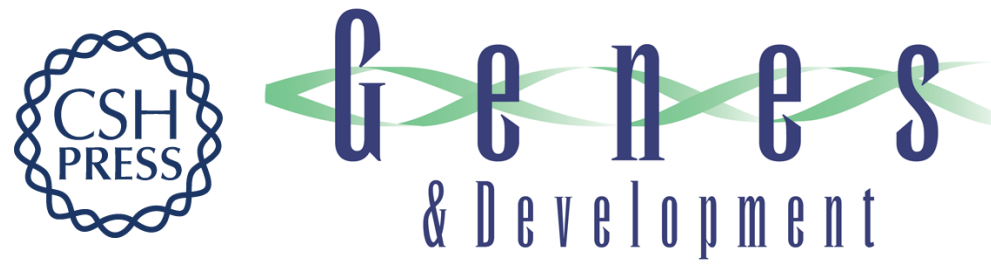

\section{Saccharomyces telomeres assume a non-nucleosomal chromatin structure.}

J H Wright, D E Gottschling and V A Zakian

Genes Dev. 1992, 6:

Access the most recent version at doi:10.1101/gad.6.2.197

References This article cites 63 articles, 26 of which can be accessed free at:

http://genesdev.cshlp.org/content/6/2/197.full.html\#ref-list-1

License

Email Alerting

Service

Receive free email alerts when new articles cite this article - sign up in the box at the top right corner of the article or click here.

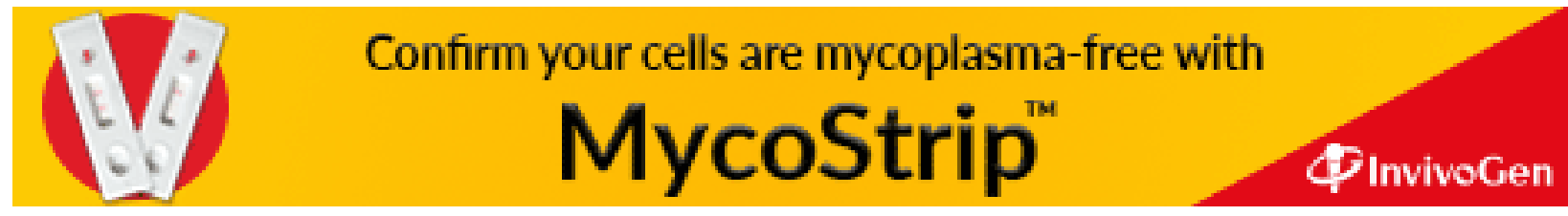

